\title{
MASJID: \\ Bentuk Manifestasi Seni dan Kebudayaan
}

\author{
Aulia Fikriarini Muchlis \\ Jurusan Teknik Arsitektur Fakultas Sains dan Teknologi UIN Maulana Malik Ibrahim Malang \\ Jalan Gajayana 50 Malang 65144. Telp. (0341) 551354 e-mail: auliaf_yahya@yahoo.com
}

\section{Abstract}

Cultural value can determine the characteristics of cultural environment in which those values believed. Hence, it is colored by the act of the society and the product of the culture. In this sense, human beings as the main actor of that existing culture. One of the visible products of the culture is its art (architecture) as the proof that best describes the situation of the culture. The architecture also influences the ups and downs of a civilization, and it is more meaningful creating the combination between human culture and the human's obedience to the God which shows harmonious relationship among human, environment, and the creator. It, then, will emerge as an Islamic new civilization, and will bring the goodness for human beings. This paper describes a mosque as not only the symbol of syi'ar Islam for praying and i'tikaf, but something that has wider role. It is the creation of Islamic cultural value. It means that the mosque was born from the knowledge that is inspired from spiritual values, therefore, it reminds and guides human to come back to the God.

Key words: mosque, culture, and art 


\section{Pendahuluan}

Manusia sebagai pelaku kehidupan di dunia ini, atau dalam al Quran disebut sebagai khalifah di muka bumi, merupakan makhluk yang memiliki akal budi, sehingga dia mutlak sebagai pelaku kebudayaan. Sebagai pelaku utama, manusia dapat mengarahkan dirinya menjadi manusia yang bermartabat dengan mengandalkan potensi transenden yang dimi-likinya, yang pada akhirnya membentuk sebuah kebudayaan. Bentuk yang muncul dari adanya kebudayaan khususnya kebuda-yaan Islam, salah satunya dapat dilihat dari adanya sebuah masjid. Keberadaannya, merupakan pusat untuk melaksanakan hubungan antara manusia dengan Allah SWT (ibadah) dan hubungan manusia dengan manusia (mu'amalah), dan merupakan hasil perpaduan antara kreativitas manusia (seni) dan nilai kerohanian.

Ditinjau secara keseluruhan, karya seni (arsitektur) telah muncul dimana dia dibutuhkan serta tidak terbatas di mana dia didirikan. Arsitektur pun turut mempengaruhi muncul dan tenggelamnya suatu kebudayaan dan peradaban. Masyarakat muslim sebagai salah satu peradaban terbesar di dunia pun tidak ketinggalan dalam menyemarakkan peradaban dengan arsitektur yang mencerminkan worldview dan nilai-nilai Islam sepanjang sejarah perkembangan dan perjalanannya di muka bumi ini. Dalam Islam, arsitektur merupakan bagian dari karya seni yang tidak pernah lepas dari keindahan yang merujuk pada kebesaran Allah SWT sebagai Sang Maha Pencipta. Hal ini memberi kesadaran, bahwa kita sebagai manusia, hanyalah hamba yang kecil dan tidak berarti apa-apa dibandingkan dengan kebesaran Allah SWT. Bahkan lebih jauh, rasa kekaguman kita terhadap keindahan dan estetika dalam arsitektur tak boleh lepas dari kepasrahan dan penyerahan diri kita terhadap kebesaran dan keagungan Allah sebagai Zat pemilik segala keindahan.

Bentuk pemikiran yang diusung dalam tulisan ini, merupakan usaha untuk menggambarkan bahwa keberadaan masjid, merupakan bentuk manifestasi dari seni dan kebudayaan, khususnya kebudayaan Islam, yang mengangkat kemajuan peradaban Islam. Karena, di manapun kemajuan kehidupan spiritual dan intelektual mencapai puncak, maka dapat dipastikan 
kreativitas akan seni (arsitektur) Islam mencapai kesempurnaan.

\section{Metode Kajian}

Metode kajian yang digunakan dalam penelitian ini adalah dengan pendataan yang dilakukan secara sekunder. Pendataan sekunder dilakukan dengan cara studi literatur yang terkait dan terintegrasi, menjadi sebuah rangkuman kajian Literatur dapat berbicara tentang masjid, sebagai pusat pengembangan dan kebudayaan Islam, masjid sebagai bentuk manifestasi arsitektur Islam, dan seni Islam dalam cakupan arsitektur, yang didapat dari jurnal, texts book, artikel serta informasi yang digali dari al Quran dan Hadist.

\section{Pembahasan}

\section{Masjid dan Kebudayaan}

Untuk sebuah bentuk hasil dari kebudayaan (masjid) perlu kiranya kita mengerti istilah culture (budaya). Dalam studi antropologi, istilah culture (budaya) dibedakan dengan istilah civilization (peradaban). Makna culture atau kebudayaan secara etimologis berkaitan dengan sesembahan (cult) yang dalam bahasa latin berarti cultus dan culture. Sementara, peradaban atau civilization berkaitan dengan kata cives yang berarti warga negara. Kalau budaya adalah pengaruh agama terhadap diri manusia, maka peradaban adalah pengaruh akal pada alam (Ridwan, 2005: 43).

Kebudayaan terdiri dari dua komponen pokok, yaitu komponen isi dan komponen wujud. Komponen wujud dari kebudayaan terdiri atas sistem budaya berupa ide dan gagasan serta sistem sosial berupa tingkah laku dan tindakan. Adapun komponen isi terdiri dari tujuh unsur universal, yaitu bahasa, sistem teknologi, sistem ekonomi, organisasi sosial, ilmu pengetahuan, agama, dan kesenian. Sistem kebudayaan terdiri atas nilai-nilai budaya berupa gagasan yang sangat berharga bagi proses kehidupan. Oleh karena itu, nilai budaya dapat menentukan karakteristik suatu lingkungan kebudayaan di mana nilai tersebut dianut. Nilai budaya langsung atau tidak langsung tentu akan diwarnai oleh tindakan-tindakan masyarakatnya serta produk kebudayaan yang bersifat materiil. 
Sedangkan pengertian masjid diantaranya menjelaskan, kata masjid terulang sebanyak dua puluh delapan kali di dalam al Quran (Shihab, 2009: 13). Dari segi bahasa, kata tersebut diambil dari akar kata sajada-yasjudu-sujud, yang berarti patuh, taat, serta tunduk dengan penuh hormat dan takzim. Meletakkan dahi, kedua tangan, lutut, dan kaki ke bumi, yang kemudian dinamai sujud oleh syariat, adalah bentuk lahiriah yang paling nyata dari makna-makna di atas. Dalam kitab suci al Quran disebutkan fungsi masjid di dalam firman-Nya: "Bertasbihlah kepada Allah di masjid-masjid yang telah diperintahkan untuk dimuliakan dan disebut nama-Nya di dalamnya pada waktu pagi dan petang, orang-orang yang tidak dilalaikan oleh perniagaan, dan tidak (pula) oleh jual-beli, atau aktivitas apa pun dan mengingat Allah, dan (dari) mendirikan shalat, membayarkan zakat, mereka takut kepada suatu hari yang (di hari itu) hati dan penglihatan menjadi guncang" (QS an Nur: 36-37).

Masih dalam ulasan (Shihab, 2009: 21) tasbih bukan hanya berarti mengucapkan Subhanallah, melainkan lebih luas lagi, sesuai dengan makna yang dicakup oleh kata tersebut beserta konteksnya. Sedangkan arti dan konteks-konteks tersebut dapat disimpulkan dengan kata taqwa. Seperti Rasul SAW bersabda: "Telah dijadikan untukku (dan untuk umatku) bumi sebagai masjid dan sarana penyucian diri (HR Bukhari dan Muslim melalui Jabir bin Abdullah).

Jika dikaitkan dengan bumi ini, masjid bukan hanya sekadar tempat sujud dan sarana penyucian. Di sini kata masjid juga tidak lagi hanya berarti bangunan tempat shalat, atau bahkan bertayamum sebagai cara bersuci pengganti wudhu, tetapi kata masjid di sini berarti juga tempat melaksanakan segala aktivitas manusia yang mencerminkan kepatuhan kepada Allah SWT. Dengan demikian, masjid menjadi pangkal tempat muslim bertolak, sekaligus pelabuhan tempatnya bersauh. Misalnya, hubungan manusia dengan Tuhannya yang berwujud seperti shalat, i'tikaf, kemudian hubungan manusia dengan manusia yang berwujud zakat fitrah, nikah, hubungan manusia dengan dirinya, seperti mengaji, mencari ilmu dan hubungan manusia dengan alam, berwujud memelihara, dan 
memanfaatkannya.

Hal ini dapat kita lihat pada masjid pertama yang dibangun oleh Rasulullah SAW, Masjid Quba', kemudian disusul dengan Masjid Nabawi di Madinah, dibangun atas dasar ketakwaan. Masjid tersebut, telah menjabarkan fungsinya sehingga lahir peranan masjid yang beraneka ragam. Sejarah mencatat tidak kurang dari sepuluh peranan yang telah diemban oleh Masjid Nabawi, yaitu sebagai: tempat ibadah (shalat, zikir), tempat konsultasi dan komunikasi (masalah ekonomi sosial budaya), tempat pendidikan, tempat santunan sosial, tempat latihan militer dan persiapannya, tempat pengobatan para korban perang, tempat perdamaian dan pengadilan sengketa, aula dan tempat menerima tamu, tempat menawan tahanan, dan pusat penerangan atau pembelaan agama. Hal ini menggambarkan bahwa masjid tidak hanya sekadar tempat ritual untuk beribadah saja, tetapi ada fungsi lain yang dapat dilakukan dengan dasar ketakwaan terhadap-Nya, yang akan dapat memberikan sebuah pemahaman tentang masjid yang lebih utuh dan integral.

Hubungan manusia yang digambarkan dengan masjid di atas, merupakan sebuah kebiasaan yang terbawa sampai detik ini dan dapat disebut pula sebuah kebudayaan Islam. Kebudayaan ini tidak akan terlepas dari peran masjid. Sebuah kebudayaan yang terlahir dari masjid, bergantung pula pada fungsi masjid. Dengan fungsi masjid yang beragam, maka akan lahir beberapa kebiasaan atau ritual yang secara berkala dilakukan, yang akan membawa kepada sebuah peradaban atau budaya baik. Dalam pembahasan di atas, kebudayaan semacam ini termasuk dalam komponen wujud berupa tingkah laku atau tindakan yang sangat berharga bagi proses kehidupan.

Perkembangan keberadaan masjid di Jawa sebagai pusat penyebaran dan kebudayaan Islam khususnya dikenalkan oleh sembilan tokoh pengembang Islam yang biasa disebut 'Walisongo'. Para penguasa kerajaan di berbagai kawasan seperti Sultan Agung (w.1645), Sultan Suriansyah di Banjarmasin Kalimantan Selatan dan Sultan Abdurrahman di Pontianak, Kalimantan Barat pada abad XIX, juga melakukan hal yang sama. Masjid Demak dan Masjid Kudus misalnya, oleh Walisongo, waktu itu dijadikan sebagai pusat 
pengislaman bagi orang Jawa dengan menarik penduduk sekitar datang ke masjid. Hampir di semua bandar di Jawa seperti Yogyakarta, Magelang, dan Purwakarta. Akhirnya, masjid menjadi bagian utama dari infrastruktur pusat pemerintahan, dan perletakannya di sebelah barat padang yang lazim disebut "alun-alun".

Masuk dan berkembangnya Islam di Indonesia membawa perubahan dalam berbagai aspek kehidupan masyarakat, hal ini dapat pula disebut sebagai kemajuan peradaban atau dalam ulasan di atas termasuk dalam komponen isi yang terurai dalam 7 bagian, diantaranya organisasi sosial, ilmu pengetahuan, agama, dan kesenian. Wujudnya, candi dan petirtaan tidak dibangun lagi, tetapi kemudian muncul masjid, surau, dan makam (Andrisijanti, 2006: 34). Sistem kasta di dalam masyarakat dihapus, arca dewa-dewa serta bentuk-bentuk zoomorphic tidak lagi dibuat. Para seniman ukir kemudian menekuni pembuatan kaligrafi, mengembangkan ragam hias flora dan geometris, serta melahirkan ragam hias stiliran. Kota-kota mempunyai komponen dan tata ruang baru. Bahkan pada abad XVII M Sultan Agung memunculkan kalender Jawa, yang pada dasarnya merupakan "perkawinan" antara kalender Saka dan Hijriyah. Masjid dan cungkub makam mengambil bentuk atap tumpang, seperti masjid Agung Demak, yang bentuk dasarnya sudah dikenal pada masa sebelumnya sebagaimana tampak pada beberapa relief candi.

Demikian pula menara masjid tempat muazin menyerukan azan, seperti menara di Masjid Menara di Kudus. Bentuk dasarnya tidak jauh berbeda dari candi gaya Jawa Timur yang langsing dan tinggi, tetapi detailnya berbeda. Bagian kepalanya berupa bangunan terbuka, relung-relungnya dangkal karena tidak berisi arca, dan hiasan relief diganti dengan tempelan piring porselin.

Untuk Masjid Kuno Bayan Lombok di Nusa Tenggara Barat terjadi pemadatan sebuah makna dari masjid sebagai tempat ibadah, menjadi masjid hanya sebagai salah satu komponen budaya masyarakat yang tidak islami lagi, antara lain disebutkan, pertama, masjid hanya sebagai orientasi pemukiman desa, masjid bukan tempat ibadah bagi masyarakat tetapi untuk 
para wali, sedangkan masyarakat hanya menyediakan sarana prasarana yang terkait dengan kelangsungan ibadah para wali. Kedua, masjid sebagai orientasi sakral. Hal ini berkaitan erat dengan kondisi sosial kultural masyarakat Desa Bayan yang sering melakukan upacara, sehingga masjid termasuk sesuatu yang sangat dikeramatkan. Ketiga, masjid hanya sebagai monumen lingkungan desa, karena masyarakat Bayan tidak menjalankan syari'at agama Islam sebenar-benarnya, yang menjalankan hanya para wali (Mulyadi, 2004: II-6).

\section{Masjid dan Arsitektur}

Dalam masyarakat tradisional, masjid didirikan atas kesepakatan komunitas setempat yang terbentuk pada saat itu juga, yang dihasilkan secara otodidak, tidak terencana maupun terstruktur, tetapi dengan latar belakang Islam yang kuat, artinya suatu kelompok masyarakat dalam kehidupannya tidak akan lepas dari lingkungan fisik maupun non fisik, yaitu alam sekitarnya, masyarakat lain dan kebudayaannya. Kenyataan seperti inilah, yang menjadikan masyarakat Indonesia umumnya, membangun masjid dengan menggunakan imajinasi yang terbentuk dari memori yang sudah mereka simpan selama ini tentang bentuk masjid. Salah satunya ditunjukkan pada penelitian Muhammad Faqih, adalah tipologi masjid diklasifikasikan berdasarkan kesamaan bentuk dasar yaitu tipologi denah dan tampang (antiangan), pada masjid yang dirancang tanpa arsitek, artinya masyarakatlah yang merancang kehadiran masjid tersebut (Fikriarini, 2004: 27).

Tipologinya dibedakan atas:

a. Tipologi Denah (ruang)

Pada ruangan shalat, imam berada pada bagian tengah paling depan, sedangkan para jamaahnya (makmum) berada di belakangnya dengan membentuk saf lurus ke samping dan tegak lurus arah kiblat. Dengan demikian, bentuk denah masjid yang paling logis dan rasional timbul dari cara-cara orang beribadah tersebut, yaitu bentuk segi empat dan bujur sangkar, bukan bentuk-bentuk yang lainnya seperti lingkaran atau bentuk 
segi banyak.

1. Tipe Denah Bujursangkar

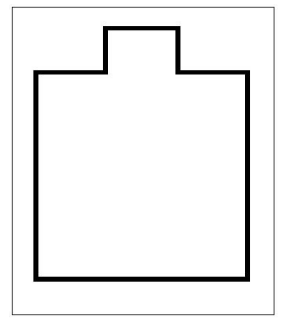

Gambar 1. Denah Bujur Sangkar (Sumber: Fikriarini, 2004: 27).

2. Tipe Denah 4 persegi panjang dengan arah memanjang arah kiblat

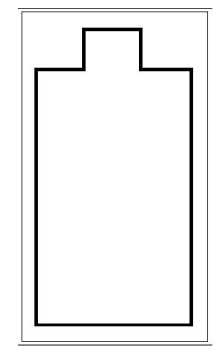

Gambar 2. Denah empat persegi panjang dengan arah memanjang arah kiblat (Sumber: Fikriarini, 2004: 27).

3. Tipe empat persegi panjang dengan sisi terpanjang tegak lurus arah kiblat.

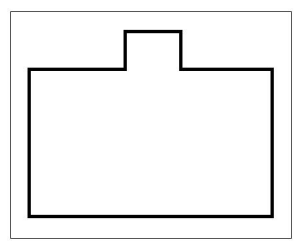

Gambar 3. Denah empat persegi panjang dengan sisi terpanjang tegak lurus arah kiblat (Sumber: Fikriarini, 2004: 27).

b. Tipologi Antiangan

Tipologi antiangan ini, berupa sebuah bidang dengan pelubangan. Bentuk-bentuk pelubangan terdiri dari 3 macam, yaitu: bentuk busur, bentuk bawang dan bentuk datar. Sedangkan tipologi antiangan sendiri, terbagi atas 
1) Tipe lempengan

Merupakan lempengan (bidang) yang dilubangi. Pelubangan beraut busur, lingkaran sangat jarang.

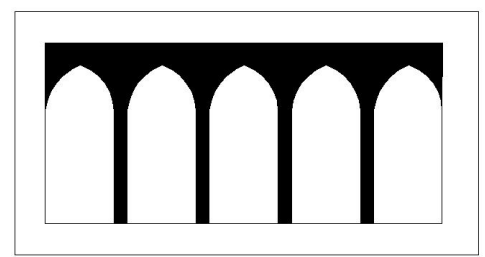

Gambar 4. Tipe Lempengan (Sumber: Fikriarini, 2004: 27).

2) Tipe Rentetan tiang

Rentetan tiang yang menopang lempengan. Lempengan tersebut dilubangi, beraut busur.

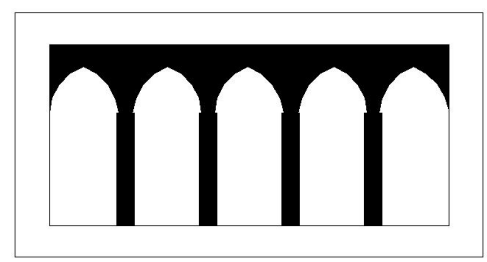

Gambar 5. Tipe Rentetan Tiang (Sumber: Fikriarini, 2004: 28).

3) Tipe taksa

Merupakan tipe taksa (ambiguos), bisa merupakan lempengan yang dilubangi, bisa merupakan rentetan tiang. Bergantung pada skala dan proporsinya.

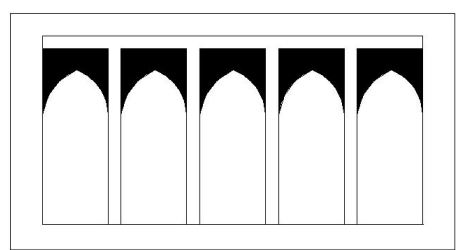

Gambar 6. Tipe Taksa (Sumber: Fikriarini, 2004: 28).

Sedangkan untuk atap, bentuk kubah masih sangat mendominasi bahkan merupakan simbol yang paling populer dan paling mudah dikenali bagi sebuah masjid. Kubah diambil dari sebagian dinasti penguasa muslimin. Misalnya, kubah Syriani berkembang dari wilayah Damaskus dan Yerusalem. Qubat al Sakhra (Golden Dome atau Dome of the Rock) di Haram ash Sharif 
(Kota Suci), Masjid al Aqsha di sentra Yerusalem, dan Masjid Agung Damaskus (Fanani, 2008: 83).

Kaum muslimin segera memberdayakan warisan itu bagi ekspresi arsitekturnya. Serangkaian bentuk ruang (denah), antiangan (tampang) dan atap kubah di atas, memberikan gambaran bahwa bentuk yang digunakan ataupun lebih tepatnya diadopsi adalah berorientasi pada objek semata, atau pendekatan yang melihat produk dari suatu peradaban sebuah masyarakat Islam semata. Padahal terdapat aspek yang lebih penting dibandingkan hanya merangkai sebuah arsitektur berlabel simbol, yaitu arsitektur Islam adalah cara membangun yang Islami sebagaimana ditentukan oleh hukum syariah, tanpa batasan terhadap tempat dan fungsi bangunan, namun lebih kepada karakter islaminya dalam hubungannya dengan desain bentuk dan dekorasi.

Dalam perkembangan selanjutnya tentang masjid, kehadirannya dipengaruhi oleh semakin bertambahnya tingkat kemampuan manusia dalam mendirikan bangunan apapun. Selain itu, permunculan bangunan masjid dikarenakan adanya dorongan tauhid, iman, dan karena adanya faktor-faktor alam yang dapat mengganggu jalannnya shalat seperti hujan, panas matahari yang berlebihan, maka muncullah bangunan masjid se-bagai karya Arsitektur. Hal ini terkait dengan sebuah Hadits al Bukhari: "Bumi ini dijadikan bagaikan masjid (tempat shalat) dan alat pensucian (tayamum) dan tempat mana saja seorang dari umatku mendapati waktu shalat, maka shalatlah ia disitu". Kemudian dapat dilihat di Surat al Taubah ayat 18: "Hanyalah yang memakmurkan masjid-masjid Allah ialah orang-orang yang beriman kepada Allah dan hari kemudian, serta tetap mendirikan shalat, menunaikan zakat dan tidak takut (kepada siapa pun) selain kepada Allah. Maka merekalah orang-orang yang diharapkan termasuk golongan orangorang yang mendapat petunjuk".

Dengan begitu, jelas sudah bahwa keberadaan masjid memberikan kontribusi tersendiri terhadap keberadaan arsitektur terutama arsitektur Islam, tetapi dalam kenyataannya banyak orang muslim dan non muslim yang meragukan fakta bahwa Islam sedikit banyak mempunyai hubungan dengan arsitektur. Keraguan mereka itu disebabkan karena mereka tidak 
tahu atau keliru, atau karena kedua-duanya (tidak tahu dan keliru). Pihak yang tidak tahu: orang-orang muslim yang tidak menyadari bahwa di seluruh dunia Islam, kesatuan arsitektural merupakan satu segi dari kesatuan umat di bawah Islam. Sebelum kedatangan Islam, kesatuan arsitektural belum ada. Sebelumnya, gaya arsitektur di mana-mana saling berbeda. Kesatuan gaya justru muncul bersama Islam, yaitu: saat arsitektur khas Islam mulai mendominasi, dengan memperbolehkan munculnya variasi-variasi untuk hal non-esensial, sehingga gaya tersebut bisa menyesuaikan diri dengan iklim setempat (al Faruqi, 2006: 5).

Serta hal-hal istimewa peninggalan nenek moyang atau pakem adat istiadat. Karakteristik gaya-gaya arsitektur yang terdapat di seluruh dunia Islam dilengkapi dan diilhami oleh Islam. Seluruh standar arsitektural tepat guna pertama-tama diterapkan di Madinah, Baitul Maqdis, Dimasyq, Qayrawan, dan Baghdad, lalu menyebar ke seluruh dunia Islam, seiring perkembangan dan penyebaran agama Islam. Standar arsitektural, sebagai unsur universal, yaitu bentuk tampilan yang telah baku disepakati oleh umat sebagai sosok tampilan sebuah masjid (Fanani, 2008: 81). Tetapi selayaknya, unsur universal tersebut perlu memenuhi tuntutan syarat yang ditinggalkan oleh Nabi Muhammad SAW. Unsur universalitas diwujudkan dalam rangkaian perwujudan arsitektural, yaitu ruang imam ditandai dengan menghadirkan mihrab, ruang utama jama'ah biasa disebut dengan haram atau zulla. Mimbar diposisikan bagi pemberi khutbah dengan dinding arah ke kiblat, di bagian atasnya ditambahkan kubah dan minaret adalah atribut tempat muadzin. Unsur-unsur yang telah disepakati ini, akan berkembang sesuai ciri lokal dan budaya setempat.

Misalnya pada Masjid Lautze, Pasar Baru, yang merupakan masjid bagi warga Tionghoa dan penduduk sekitar area tersebut. Masjid ini berbeda bentuknya dengan lazimnya masjid yang ada. Bangunan berlantai empat gabungan dua unit ruko ini kental dengan nuansa Tionghoa. Dua pintu utama di bagian depan dicat merah menyala sangat kontras dengan masjid pada umumnya yang berwarna hijau atau kuning. Hal ini terjadi karena masjid ini didirikan dan dikembangkan oleh warga Tionghoa yang masuk 
Islam. Kalau masuk ke dalam, di belakang mimbar digantung sepasang kaligrafi Arab ala Shu Fa atau kaligrafi Tionghoa asli buatan Beijing.
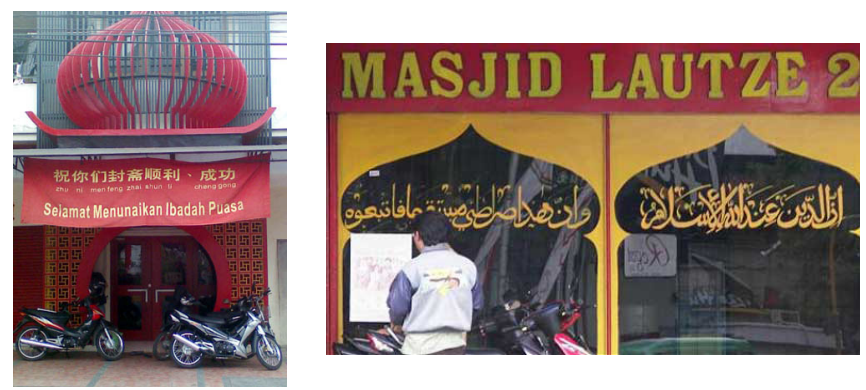

Gambar 7. Masjid Lautze (Sumber: foto detik.com dan swaramuslim.com).

Berbeda dengan masjid lainnya yang berorientasi hanya pada simbol semata, Achmad Noe'man menawarkan sebuah wacana baru dalam perkembangan arsitektur masjid di Indonesia. Noe'man menekankan perancangan masjidnya pada kekuatan pemikiran, logis, rasional dengan hembusan arsitektur modern dan terpadu de-ngan pemikiran Islami (Utami, 2004: II-33). Lebih lanjut dijelaskan, Noe'man tidak menggunakan tempelan ornamen, tidak pula menggunakan simbol, yang seringkali tidak rasional dan mengada-ada dan akan menyesatkan orang. Visualisasi yang hadir adalah sederhana (simple), bersih (clean) dan jelas (clear), dengan alasan konsep tersebut mencerminkan cara pandang yang Islami dan tidak berlebih-lebihan (mubazir), serta konsep Islam yang menyatakan bahwa agama itu ditujukan untuk orang-orang yang berpikir rasional. Karena pada dasarnya Islam itu sangat rasional.
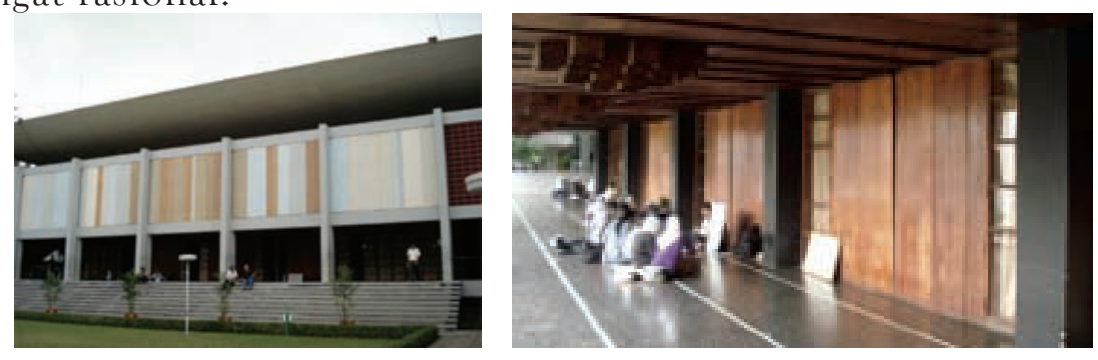

el-Harakah, Vol. 11, No.1, Tahun 2009 
Gambar 8. Masjid Salaman ITB Karya Ach. Noe'man (Sumber: galeri.myqur'an.org).

\section{Masjid sebagai Seni (Arsitektur) Islam}

Cara penyebaran Islam yang dibawa oleh para wali, adalah melalui seni, misalnya seni sastra, seni pertunjukan, seni musik, seni pahat, dan seni bangunan. Seni bangunan juga dipakai sebagai sarana untuk penyebaran agama Islam di Nusantara. Salah satu contohnya adalah gaya arsitektur yang dipilih dalam membangun masjid. Sebagaimana diketahui gaya arsitektur mesjid kuno yang disebut gaya nusantara dikembangkan dari arsitektur yang sudah dikenal sebelumnya, namun disesuaikan dengan kebutuhan peribadatan agama Islam di daerah masing-masing.

Seni bangunan ini dapat kita katakan sebagai karya arsitektur Islam, seperti yang telah dibahas di atas. Namun, selama ini kenyataan yang hadir adalah karya seni yang bersifat simbolis. Setidaknya seni Islam termasuk arsitektur Islam, mengandung tiga hal (Nasr, 2004: 316):

1. Mencerminkan nilai religius, sehingga tidak ada yang disebut seni sekuler. Dalam Islam pun ditegaskan tidak ada dikotomi religius dan sekuler. Apa yang disebut kekuatan atau unsur sekuler dalam masyarakat Islam, selalu dianggap memiliki pengertian religius, seperti halnya hukum Ilahi yang secara spesifik memiliki unsur religius. Hal semacam inilah yang perlu ditegaskan dan ditekankan sekali lagi kepada masyarakat Islam, sehingga pengaplikasian seni dalam bidang apapun termasuk arsitektur, mampu menampilkan nilai religius baik dalam tampilan fisik maupun secara maknawi.

2. Menjelaskan kualitas spritualitas yang bersifat santun, akibat pengaruh nilai-nilai sufisme

3. Ada hubungan yang halus dan saling melengkapi antara masjid dan istana (dalam hal ini istana bisa diselaraskan sebagai pemerintahan), dalam hal perlindungan, pengunaan dan fungsi berbagai seni, termasuk arsitektur Islam, masjid di antaranya. 
Seni Islam, dalam hal ini masjid termasuk dalam katagori seni suci. Kekosongan, kesederhanaan bentuk serta pola, menunjukkan status ontologis dunia sebagai sesuatu yang papa dan miskin dihadapan Allah SWT. Ruang yang sunyi merefleksikan kedamaian, sedangkan lengkungan dan kolom ruangan adalah ritme yang menjelaskan fase-fase manusia, datang dan kembali kepada-Nya (Nasr, 2004: 324).

Karena arsitektur juga berkaitan erat dengan lingkungan di mana dia berada, maka kekuatan dan prinsip yang mendasari kehadiran arsitektur masjid, bisa karena pengaruh sosio politik pada saat itu, semisal ketika penyebaran agama Islam terjadi. Namun, yang paling penting bagaimana mengembangkan keberadaan masjid ini dengan pandangan-dunia (world view) Islam sendiri. Sumber seni Islam harus dicari di dalam realitas-realitas batin (haqaiq) al Quran yang merupakan realitas kosmos dan realitas spiritual substansi nabawi. Selain itu, seni Islam termasuk arsitektur Islam didasarkan atas hikmah yakni pengetahuan yang diilhami oleh nilai-nilai spiritual (Nasr, 2004: 320). Hal ini dapat kita lihat pada bangunan Masjid Syah di Isfahan yang didirikan pada tahun 773 (masa Dinasti Abbasiyyah), dalam rancangannya dibangun dengan pola geometri dan arabeska (kaligrafi tradisional).

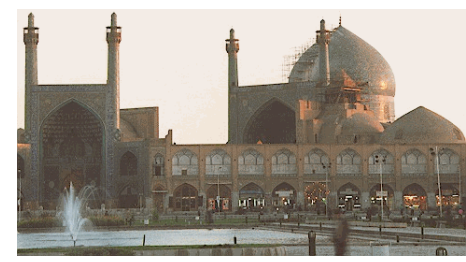

Gambar 9. Masjid Syah di Ishafan (www.geocities.com).

\section{Simpulan}

Gambaran di atas, telah memberikan penjelasan tentang sebuah kebudayaan lahir dari penyebaran agama Islam melalui keberadaan sebuah masjid. Masing-masing tempat akan menampilkan karakteristik yang berbeda, karena nilai budaya yang mereka anut berbeda, walaupun sama-sama beragama 
Islam. Apabila nilai budaya yang mereka anut tidak dalam lingkaran syariat Islam, karena sudah berbaur dengan kebiasaan masyarakat setempat, maka bentuk masjid dan keberadaannya bisa hanya bersifat simbolis saja. Namun apabila sosial kultur masyarakatnya sangat menerima keberadaan sebuah masjid, maka bisa jadi masjid akan mengalami perubahan baik dari segi maknawi, untuk beribadat saja sampai pada terhadap kehidupan bermasyarakatnya seperti yang diajarkan oleh rasul, dan perubahan fisik bangunan yang tidak mengandalkan simbol semata tetapi berupa pemikiran logis, rasional dan yang tidak kalah penting adalah pemikiran islami. Pengaruh kebudayaan terhadap hadirnya seni Islam (arsitektur), khususnya masjid harus digali dan mengekspresikan dimensi-dimensi spiritual, merefleksikan prinsip-prinsip tauhid, sehingga ia mampu mengi-ngatkan dan menuntun manusia untuk kembali kepada Allah SWT. Tidak ketinggalan pula, prinsip keindahan dalam sebuah masjid tetap merujuk pada hakikat yang sama dibalik agama Islam dan tradisi masing-masing tempat, untuk menyatukan sebuah konsep pemahaman transenden, atau dapat dikatakan masjid sebagai karya seni (arsitektur) Islam, harus lahir dari nilai-nilai spiritualitas Islam yang tampilan fisiknya dipengaruhi dari karakter sosial budaya setempat.

\section{Daftar Pustaka}

Al Faruqi, Ismail Raji A. 2006. Pandangan Keliru dalam Arsitektur Islam. bina-ul-barakah.blogspot.com. [10 Februari 2009]. http://www. bksnt-jogja.com

Adrisijanti, Inajati. 2006. Islam Salah Satu Akar Budaya Indonesia. www. bksnt-jogja.com/bpsnt. [10 februari 2009].

Fanani, Achmad. 2008. Arsitektur Masjid. Jakarta: Sanggit Reka Pustaka.

Fikriarini M, Aulia. 2004. Pengaruh Bentukan Arsitektural Masjid Terhadap Distribusi Daylight Kajian Tipologi Arsitektural Masjid Tanpa Arsitek [tesis]. Surabaya: ITS Surabaya.

Mulyadi, Lalu dkk. 2004. Fenomena Masjid Kuno Bayan Lombok Nusa Tenggara 
Barat. Prosiding Aplikasi Arsitektur Islam Pada Lingkungan Binaan. hlm 16-17 Juni 2004: II-6.

Nasr, Sayyid Husein.2004. Manifestasi Dimensi Spiritual Pemikiran Seni S. Husein Nasr. Dalam Khudori Sholeh, Wacana Baru Filsafat Islam. Yogyakarta: Pustaka Pelajar Offset.

Ridwan. 2005. Dialektika Islam dengan Budaya Jawa. Volume 3 (1): DialektikaIslam dengan Budaya-Jawa. bda.files.wordpress.com. pdf. [10 Februari 2009]

Shihab, Quraish. tt. Masjid. (media.isnet.org/v01/islam/Quraish/Wawasan/ index.html. [10 Februari 2009].

Utami. 2004. Integrasi Konsep Islami dan Modernitas pada Konsep Pemikiran dan Arsitektur Masjid Karya-karya Achmad Noe'man. Prosiding Aplikasi Arsitektur Islam Pada Lingkungan Binaan, 16-17 Juni 2004: II-33.

http: //www.detik.com

http://www.geocities.com

http://www.swaramuslim.com 